\title{
Who are you and what do you value? Investigating the role of personality traits and customer-perceived value in online customer engagement
}

Article

Accepted Version

Marbach, J., Lages, C. R. and Nunan, D. (2016) Who are you and what do you value? Investigating the role of personality traits and customer-perceived value in online customer engagement. Journal of Marketing Management, 32 (5-6). pp. 502-525. ISSN 1472-1376 doi:

https://doi.org/10.1080/0267257X.2015.1128472 Available at https://centaur.reading.ac.uk/66234/

It is advisable to refer to the publisher's version if you intend to cite from the work. See Guidance on citing.

Published version at: http://www.tandfonline.com/doi/abs/10.1080/0267257X.2015.1128472

To link to this article DOI: http://dx.doi.org/10.1080/0267257X.2015.1128472

Publisher: Taylor \& Francis

All outputs in CentAUR are protected by Intellectual Property Rights law, including copyright law. Copyright and IPR is retained by the creators or other copyright holders. Terms and conditions for use of this material are defined in the End User Agreement. 


\section{www.reading.ac.uk/centaur}

\section{CentAUR}

Central Archive at the University of Reading

Reading's research outputs online 
This is an electronic version of an article published in Journal of Marketing Management (2016), 32, 5-6 (Special Issue: Customer Engagement).

Who are you and what do you value? Investigating the role of personality traits and customer-perceived value in online customer engagement is available online at:

http://www.tandfonline.com/doi/abs/10.1080/0267257X.2015.1128472 
Who are you and what do you value? Investigating the role of personality traits and customer-perceived value in online customer engagement

Julia Marbach, Marketing \& Reputation, Henley Business School, University of Reading Corresponding author

Henley Business School,

University of Reading,

Whiteknights Campus,

RG6 6UD, UK

Email: j.marbach@pgr.reading.ac.uk

Tel.: +44 (0) 1183785044

Cristiana Raquel Lages, Marketing \& Reputation, Henley Business School, University of Reading

Email: c.r.lages@henley.ac.uk

Tel.: +44 (0) 1183787941

Daniel Nunan, Marketing \& Reputation, Henley Business School, University of Reading Email: d.f.nunan@henley.ac.uk

Tel.: +44 (0) 1183785044

\section{Acknowledgment}

Julia Marbach is grateful to the Henley Business School for the financial support of her PhD. Special thanks are due to Rasha El Gendi and Stephan Hauser for helpful comments on previous versions of this article. 


\begin{abstract}
While the importance of customer engagement has been widely acknowledged a gap remains in terms of our understanding of how customers engage with products and services delivered online. Addressing this gap is important given the increasing proportion of time spent interacting with companies online and the key role of customer engagement in delivering an effective customer experience. This paper seeks to address this gap through developing a theoretical framework of online customer engagement anchored in twenty-eight semistructured interviews with members of social media brand communities. This study's contribution to the customer engagement literature is twofold. Firstly, the study will bring new insights regarding personality traits as an antecedent of online customer engagement (OCE) and, secondly, customer-perceived value emerges as a novel consequence of OCE. Understanding what personality traits drive customers to engage online and what value they perceive to receive in this digital age can help managers to better segment and evaluate their customers' online engagement. Online brand communities can be improved accordingly.
\end{abstract}

Keywords: customer engagement; personality traits; customer-perceived value; online brand communities; social media

\title{
Declaration of Conflicting Interests
}

The authors declare no potential conflicts of interest with respect to the research, authorship, and/or publication of this article. 


\section{Introduction}

Managers are increasingly concerned with how to best engage customers in order to develop favourable customer experiences. These experiences are essential in building sustainable differentiation (Vivek, Beatty, \& Morgan, 2012) and create a long-term relationship between the brand and the customers (Rose, Hair, \& Clark, 2010). Customer engagement goes further than satisfaction and loyalty and therefore provides a real competitive advantage that drives successful businesses (Kumar, Petersen, \& Leone, 2010; Prahalad \& Ramaswamy, 2004). In response to this changing environment, customer engagement has been explored extensively in the academic literature in recent years (Brodie, Hollebeek, Juric, \& Ilic, 2011; Brodie, Ilic, Juric, \& Hollebeek, 2013; Hollebeek, Glynn, \& Brodie, 2014). However, less attention has been given to online customer engagement (OCE) in brand communities and, in particular, the antecedents and consequences of online customer engagement (Brodie et al., 2013). Given that increasing numbers of customers raise their voices online and OCE remains an underresearched field in the academic literature to date (Brodie et al., 2013), the purpose of this study is to address this gap in the customer engagement literature.

The contributions of this paper are twofold. Based on the semi-structured exploratory interviews: (i) seven personality traits emerged as antecedents of online customer engagement, three of which are novel antecedents, and (ii) customer-perceived value emerged as a novel consequence. For managers, this study helps companies aiming to improve their online brand communities' customer engagement by suggesting which type of customers (in terms of personality traits) are more likely to engage online and by exploring the customer-perceived value of engaging online. This paper is structured as follows. We begin by reviewing the literature on customer engagement. Secondly, an empirical study of 28 semi-structured exploratory interviews is presented and a conceptual framework developed. Finally, managerial implications, limitations and directions for future research are discussed. 


\section{Customer engagement - a theoretical framework}

Customer engagement may be defined as a multidimensional concept, reflecting a psychological state occurring by virtue of interactive customer experiences with focal objects within service relationships (Brodie et al., 2011). The customer engagement literature has its foundations within relationship marketing theory and draws on the theory of interactive experiences (Brodie et al., 2011). These theories were first explored by the Nordic school (Grönroos, 2000; Gummesson, 1994) and, more recently, as part of service dominant logic (Vargo \& Lusch, 2004, 2008). Very few articles used the terms 'customer engagement', 'consumer engagement' or 'brand engagement' prior to 2005, indicating both that the concept is a relatively new research topic and that the terms are closely related (Brodie et al., 2011). In this paper, we will use the concept of customer engagement because the participants of the study have been identified as actual customers of the brands they engage with on Facebook. While there is still no consensus about the elements that constitute customer engagement, several authors acknowledge that the engagement concept consists of three dimensions, namely: cognitive, emotional and behavioural (Algesheimer, Dholakia, \& Hermann, 2005; Brodie et al., 2011; Brodie et al., 2013; Hollebeek, 2011; Macy \& Schneider, 2008; Mollen \& Wilson, 2010; Patterson, Yu, \& De Ruyter, 2006; Vivek et al., 2012). Many other authors across all academic disciplines directly or, in most cases, indirectly confirm the existence of one or more of these dimensions in their research on engagement (Bejerholm \& Eklund, 2007; Matthews et al., 2010; Norris, Pignal, \& Lipps, 2003).

In addition to these three dimensions, customer engagement might also have a motivational basis (Hollebeek, 2011). Nevertheless, the dominant stance in the literature regards engagement as a behavioural manifestation, on the basis that taking action is what really differentiates individuals who engage from those who do not (Kumar, Petersen, et al., 2010; Sawhney, Verona, \& Prandelli, 2005; Verhoef, Frances, \& Hoekstra, 2002). However, some studies see 
the concept as emotional (Catteeuw, Flynn, \& Vonderhorst, 2007; Roberts \& Davenport, 2002) or cognitive in nature (Guthrie \& Cox, 2001), whereas others justify all three dimensions (Brodie et al., 2013; Calder, Malthouse, \& Schaedel, 2009; Mollen \&Wilson, 2010). This threedimensional conceptualisation has also been adopted by other engagement research areas, namely employee engagement (Macy \& Schneider, 2008; May, Gilson, \& Harter, 2004), job and organisation engagement (Koyuncu, Burke, \& Fiksenbaum, 2006; Saks, 2006; Schaufeli, Salanova, Gonzalez-Roma, \& Bakker, 2002; Seppälä et al., 2009).

To understand the concept of customer engagement it is also necessary to distinguish between the concept of participation and the concept of involvement. While involvement is defined as an individual's level of interest and personal relevance in relation to an object in terms of his or her own values, self-concept or goals (Mittal, 1995; Zaichkowsky, 1985), participation is the degree to which customers produce as well as deliver services (Bolton \& Saxena-Iyer, 2009). The main difference between customer engagement and these two concepts is that involvement and participation do not reflect interactive, co-creative experiences. Mollen and Wilson (2010) highlight that customer engagement goes beyond mere involvement. Firstly, engagement encompasses an interactive relationship with the engaged object; secondly, the emergence of an individual's perceived experiential value is required, in addition to the instrumental value obtained from specific brand interactions (Mollen \& Wilson, 2010) usually associated with involvement. Moreover, customer engagement refers to voluntary and discretionary customer behaviours towards a company (Verleye, Gemmel, \& Rangarajan, 2013) and these customers are driven by their own unique purposes or intentions that can either be beneficial or unbeneficial for a company (Brodie et al., 2013; Jaakkola \& Alexander, 2014). Accordingly, in line with Brodie et al. (2013) this study defines online customer engagement as a psychological state comprised of cognitive, emotional and behavioural dimensions. 
While numerous antecedents and consequences of customer engagement have been theoretically investigated in the literature, most of them have not been empirically tested. In particular, the nature of the concept of OCE and its specific drivers and outcomes remains nebulous. As suggested by a literature review of customer engagement in online brand communities, the relationships between OCE and personality traits, as well as customerperceived value, have been overlooked. Next, this paper discusses the limited literature covering these two concepts' relationship with OCE.

\section{The roles of personality traits and customer-perceived value}

Personality traits have been mentioned as research areas of relevance when studying online customer engagement (Wirtz et al., 2013). Previous research has recognised that customer engagement might be related to value creation in general (Higgins \& Scholar, 2009; Hollebeek, 2013; Jaakkola \& Alexander, 2014; Kumar, Aksoy, et al., 2010; McAlexander, Schouten, \& Koenig, 2002) while others hypothesised a relationship between online brand community practices and customer value (Misra, Mukherjee, \& Peterson, 2008; Porter, Devaraj, \& Sun, 2013; Schau, Muñiz, \& Arnould, 2009; Seraj, 2012). Before conducting the exploratory study, we will now explore these two concepts.

\section{Personality traits}

Personality traits often reflect what people value, prefer and are motivated by (Harris \& Lee, 2004). Traits are usually stable over time and, although these can vary from occasion to occasion, there is a core of consistency defining the true nature of an individual (Ajzen, 2005). The Big Five is one of the most widely applied personality instruments in psychology and is considered by many authors to be the best paradigm for personality structure because it is replicable (Costa \& McCrae, 1992a; Digman, 1990). Moreover, the Big Five have provided the framework for numerous studies to show the validity of the traits as predictors of different 
human behaviours (Barrick \& Mount, 1991; Digman \& Takemoto-Chock, 1981; Hirschfeld, Jordan, Thomas, \& Feild, 2008; Tett, Jackson, \& Rothstein, 1991). The Big Five factors are: extroversion/introversion, agreeableness/disagreeableness, conscientiousness, neuroticism (also referred to as emotional stability) and openness to experience (also referred to as culture, intellect or imagination). While research has shown that the Big Five are a key framework of personality traits, debate exists regarding whether these five dimensions are enough to describe human behaviour (Paunonen \& Ashton, 2001). This study follows the contention that the five factors only provide a limited account of an individual's personality (Block, 1995). Hence, other studies that investigated additional personality traits combined with the Big Five have been considered, namely: the need for activity (Licata, Mowen, Harris, \& Brown, 2003), the need for arousal (Mowen \& Spears, 1999), the need for learning, and altruism (Mowen \& Sujan, 2005). These additional traits have been chosen in this study because they have been investigated together with the Big Five and thus they provide a more comprehensive and detailed amount of personality traits. Moreover, this comprehensive set of personality traits will shed more light on personality traits' role as an antecedent of online customer engagement. The Big Five personality traits have been investigated in relation to Facebook use (Hughes, Rowe, \& Lee, 2012; Ross et al., 2009; Ryan \& Xenos, 2011; Seidman, 2013) and Facebook engagement (Gosling \& Augustine, 2011), but no research thus far has investigated the Big Five together with the proposed four additional traits in relation to online customer engagement. 
Customer-perceived value: social value, play, excellence, efficiency, aesthetic value, altruistic value

Recognising that the customer value construct is one of the cornerstones of the marketing discipline (Mustak, 2014), this paper focuses on customer-perceived value. Value may be broadly defined as the ratio of perceived benefits to perceived sacrifices (Monroe, 1979). Customer-perceived value, in particular is defined as 'a cognitive trade-off of sacrifices and benefits which are associated with consumption practices' (Zeithaml, 1988, p. 14). In this definition the concept is seen as unidimensional in nature whereas a more recent definition describes it as an 'interactive, relativistic preference experience' (Holbrook, 1999, p. 5) and thus multidimensional. There is no consensus in terms of its measurement: while some authors regard it as a unidimensional construct (Dodds, Monroe, \& Grewal, 1991; Monroe, 1979; Zeithaml, 1988), others consider it a multidimensional construct (Holbrook, 1999; Ruiz, Gremler, Washburn, \& Carrión, 2008; Sheth, Newman, \& Gross, 1991). The latter is in line with service-dominant logic (Vargo \& Lusch, 2004), which argues that customers are always co-creators of value. Moreover, as the multidimensional approach is the most comprehensive (Leroi-Werelds, Streukens, Brady, \& Swinnen, 2014), this study builds on the definition of Holbrook (1999) and the operationalisation of six value types namely social value, play, excellence, efficiency, aesthetic value and altruistic value (Leroi-Werelds et al., 2014; SánchezFernández, Iniesta-Bonillo, \& Holbrook, 2009).

\section{Research approach}

Given the scarcity of research on these relationships, this exploratory study allows the development of specific research propositions and a conceptual framework for online customer engagement. Twenty-eight semi-structured, in-depth, face-to-face interviews were conducted, by one interviewer, with members and non-members of a Facebook brand community. Twentythree different Facebook brand communities were mentioned by participants and four 
participants stated that they do not interact with any brand on Facebook. Fifteen interviewees were female and thirteen male, with an age range between 19 and 40 years old. Interviews were conducted over a period of five weeks and each interview lasted between 40 to 60 minutes. Respondents were asked to name a Facebook brand page they are a member of and answer a number of questions relating to that page. The aim of the interviews was to gain insights into the nature of online customer engagement as well as its drivers and outcomes. Accordingly, respondents explained in their own words what engagement with a brand on Facebook means to them by answering questions such as 'How do you engage/interact with the brand?' and 'What are the main reasons you engage/interact with this brand or other customers on Facebook?'. Following these questions, each interviewee was shown the definition of online customer engagement (Brodie et al., 2013) in order to ensure a shared understanding of the concept. Respondents were then asked to think about the nine different personality traits and their underlying definitions and measurement items. Interviewees were requested to indicate whether, as far as they saw themselves, the description of each trait fitted their personality or not. The definitions and measurement items of personality traits have been derived from the existing literature (e.g. Costa \& McCrae, 1992a; Eysenck, 1991; Licata et al., 2003; Mowen \& Spears, 1999; Mowen \& Sujan, 2005). After expressing some opinions about their personality, respondents were asked if they thought specific personality traits influenced their online engagement with a brand or other individuals on Facebook. If they indicated an influence, they were asked to illustrate with an example. Participants were also asked to describe why they engage online and whether they perceive value in engaging with the brand and other members on the Facebook brand page.

\section{Data analysis}

This study followed the six recommended steps to analyse qualitative data (Miles \& Huberman, 2013), namely: (1) categorisation; (2) unitising data; (3) recognising relationships and 
developing categories; (4) creating data displays for examining the data; (5) developing propositions; and (6) drawing conclusions. Selective coding was used, which was based on existing literature in the area of personality trait concepts (e.g. Licata et al., 2003; Mowen \& Spears, 1999; Mowen \& Sujan, 2005) and customer-perceived value (e.g. Holbrook, 1999). Two independent judges compared emergent themes and interpreted each interview to increase the study's internal validity and reliability. A memo was completed that reflected each judges' interpretation. No major disagreement occurred regarding the emergent themes. When minor disagreements emerged, the judges compared the memos, discussed the issues and reached agreement (Holloway \& Beatty, 2003). The intercoder reliability was 94.3\%, indicating a high level of reliability (Lombard, Snyder-Duch, \& Bracken, 2003). Two major themes emerged, namely: a link between personality traits and online customer engagement, and a link between the latter and customer-perceived value. As a result of the exploratory interviews the following research propositions emerged and the conceptual framework, anchored in both the existing customer engagement literature and the interview findings, has been developed.

\section{Findings}

Personality traits and online customer engagement

\section{Extroversion/introversion}

Extroversion describes the degree to which a person is sociable and outgoing (Mottram \& Fleming, 2009). Introverts, on the other hand, find more pleasure in solitary activities, like to keep their feelings to themselves, tend to be less open-minded, less close to others and more suspicious (Evans, 1941; Eysenck, 1991). Extroversion has been linked to social media usage (Correa, Willard, \& Zúniga, 2010) and extroverts have been found to be members of more groups on Facebook as they prefer to be in social situations rather than alone (Ross et al., 2009). On the other extreme, introverted people might engage less online as they are not as sociable as extroverts (Mottram \& Fleming, 2009; Raja \& John, 2010) and tend to have fewer friends 
(Asendorpf \& Wilpers, 1998). The following respondents'statements provide further support for the suggestion that introverts engage less online:

I am not a member of a Facebook brand page. [...] Maybe if some of my closest friends would recommend a certain product I might try it but I will not go online to read about it as I don't know these people so why should I trust them? (Male, 37)

Well, I think I do not enjoy communicating with the unknown. Thus, I am basically not very comfortable with online activities, particularly on Facebook, which is widely open to un-specified individuals. (Male, 30)

Whereas respondents that described themselves as extrovert and outgoing show a high level of engagement by stating:

When I watch this show [The X Factor] it is great fun to interact with other viewers of this television programme [online]. There is always something to talk about if it's someone's great voice or horrible cloth[es]. It's always good to hear the latest gossip and stay up to date. (Female, 19)

Another respondent stated:

I love the Australia.com Facebook brand page as it connects me to people from all over the world who have the same passion for the country. I did one year work and travel there and I met so many amazing people. Thanks to the page I got to know people who were also planning to go there even before I actually went there in person. (Female, 24)

Therefore, it is proposed that: 
RP1: Introversion is negatively related to the a) cognitive processing dimension of $O C E, b$ ) emotional dimension of $O C E$ and c) behavioural dimension of $O C E$.

In total, 18 out of 28 participants either stated that extroversion might drive their online engagement or described themselves as rather introvert and thus unlikely to engage online.

\section{Agreeableness/disagreeableness}

Agreeableness refers to the general warmth of feelings towards others (Brown, Mowen, Donovan, \& Licata, 2002) and reflects how friendly an individual is (Costa \& McCrae, 1992b). Disagreeableness is the opposite of agreeableness and these individuals tend to be unfriendly, uncooperative, suspicious, sceptic and their self-interest is their first priority (Eysenck, 1991). Usually disagreeable individuals don't care about the well-being of others and might not appreciate other individuals' contributions in online brand communities and thus are less likely to share experiences online or engage with peers in online brand communities. The following statements suggest that disagreeableness might be negatively related to customer engagement in online brand communities by highlighting that individuals that described themselves as rather disagreeable might not appreciate other customers' comments or experiences and also do not want to share their experiences with strangers. They are more self-focused and like to rely on themselves and therefore see engaging online as a waste of their precious time.

In general, I am not sharing my product experiences with other people. I mean when I speak to some friends and they say, 'oh I like this product' and I have tried it too I will comment on it but I will not waste my time in sharing my experience of it with others online. (Female, 34) 
I am quite busy with my job so I don't want to spend the whole evening in front of my laptop too. I like to do sports or something that benefits myself after work. If I see a new product I just buy it and try it. I mean every person is different some like it whilst others might not like it. I definitely prefer to make my own experiences instead of reading and listening to other people's opinions online. (Male, 29)

The following proposition is suggested and supported by 13 out of 28 interviewees:

RP2: Disagreeableness is negatively related to the a) cognitive processing dimension of OCE b) emotional dimension of OCE and c) behavioural dimension of OCE.

\section{Conscientiousness}

Conscientiousness is the degree of orderliness, organisation and precision (Brown et al., 2002) but it also refers to work ethics and thoroughness (Costa \& McCrae, 1992a). Interpersonal relationships are less important for conscientious individuals (Tsao, 2013) and they have more of a tendency to meet deadlines and be responsible with their obligations (Ross et al., 2009). Therefore, this study argues that conscientious individuals use the internet more for the improvement of work skills rather than building relationships with peers in an online community (Tsao, 2013), and thus they may see engaging in an online brand community as a distraction from more important tasks (Butt \& Phillips, 2008). This argument is in line with past studies that found a negative correlation between conscientiousness and the amount of time spent on Facebook (Amichai-Hamburger \& Ben-Artzi, 2000; Ryan \& Xenos, 2011; Wilson, Fornasier, \& White, 2010). The following supporting comments were given by conscientious respondents and show that engagement levels of individuals high on conscientiousness are rather low; they only use the community to find relevant information but don't engage with peers because they aim to be efficient and prefer to focus on issues they perceive as really 
important. Hence, they might use the Facebook brand page for information but they do not actively engage with the brand page or other users.

I am quite busy. I have a lot on my plate. I don't have a lot of time to engage online. When I need something I look it up quickly. I don't have time to read 100 customer reviews. I try to be focused on stuff I really need. (Female, 35)

I like the Mercedes-Benz Facebook page, as I need it for my job as an automobile sales manager. It's good to check new posts daily to be up to date. In my job I have to communicate with people the whole day so I don't really enjoy engaging with other Mercedes-Benz enthusiasts or drivers online. (Male, 36)

Thus, the following research proposition is suggested, which is supported by 7 out of 28 interviewees:

RP3: Conscientiousness is negatively related to the a) cognitive processing dimension of OCE b) emotional dimension of OCE and c) behavioural dimension of OCE.

Openness to experiences

People who are open-minded to experiences have more curiosity as well as imagination and are more flexible in their thinking (Madjar, 2008; McCrae \& Costa, 1991). Individuals who are more open to experience are more likely to have a broader range of interests and therefore also pursue those interests through a wider variety of means (Butt \& Phillips, 2008). Additionally, they tend to seek more information (McElroy, Hendrickson, Townsend, \& DeMarie, 2007) and are broader-minded and tolerant to different perspectives. Hence, they also seek more opportunities to learn something new (McCrae \& Costa, 1991) and will be more likely to engage online. Past studies suggest that individuals who are more open to experience tend to 
be more sociable via Facebook and have a greater tendency to use social media in general (Amichai-Hamburger \& Vinitzky, 2010; Correa et al., 2010; Ross et al., 2009). Respondents (16 out of 28) described a positive relationship between openness to experience and customer engagement in online brand communities in the following comments:

I like to engage with the Equinox Facebook page as they regularly organise events with all the members of the club. It's a great experience to get to know new people and the Facebook page keeps everyone connected. (Male, 25)

Another respondent mentioned:

My dad has been a VW driver all of his life. When I was 18, I got my first VW and started sharing his passion for the brand. I am part of several VW communities online; one of them is their Facebook community. There are meetings every few months where VW fans meet and show off their cars. Every time I go, I meet new people and I get a lot of ideas and information. The online brand communities are perfect to get and keep in touch with other enthusiasts. (Male, 23)

These statements show that respondents with a high need for new experiences tend to engage with Facebook brand pages and its users at a higher level. They use these brand pages to get to know other individuals that might share the same interests. Accordingly, the following research proposition emerges:

RP4: Openness to Experience is positively related to the a) cognitive processing dimension of OCE, b) emotional dimension of OCE and c) behavioural dimension of OCE.

Neuroticism

Neuroticism refers to the extent to which the emotions of an individual vary (Brown et al., 2002). If a person has a high level of neuroticism they are less able to deal with stress (McCrae 
\& Costa, 1991). A new stream of research anchored in the loneliness theory indicates that individuals high in neuroticism use the internet on a frequent basis in order to avoid loneliness (Amichai-Hamburger \& Ben-Artzi, 2003; Butt \& Phillips, 2008; Correa et al., 2010; Hughes et al., 2012; Ryan \& Xenos, 2011). For this reason, individuals high in neuroticism also appreciate the community (Malone, Pillow, \& Osman, 2012) and may pursue acceptance and social contact through social networking sites (Malone et al., 2012). For instance, they can find opportunities online to connect and bond with others and get support for situations they feel would burden others in an offline environment (Judge, Erez, Bono, \& Thoresen, 2011). Although, no support was found in the interviews, it is proposed that:

RP5: Neuroticism is positively related to the a) cognitive processing dimension of $O C E, b$ ) emotional dimension of $O C E$ and c) behavioural dimension of $O C E$.

\section{Need for activity}

Need for activity is the enduring motive to be doing something on a continuous basis (Mowen \& Sujan, 2005). Individuals who have a high need for activity have the desire to keep being busy all the time and stay active (Licata et al., 2003). One can argue that a customer who is highly engaged in interactive experiences that go beyond transactions (Brodie et al., 2011; Verhoef, Reinartz, \& Krafft, 2010; Vivek et al., 2012) might be so because they are very active and like to keep busy all the time. Hence, this research argues that need for activity may also predict customer engagement in online brand communities - people who have a higher need for activity may be more motivated to engage online, even after a long working day. The following quotes support this assumption by showing that individuals with a high need for activity are highly engaged online to keep themselves busy. In total, 9 out of 28 interviewees stated that need for activity drives their engagement with Facebook brand pages: 
I engage in several Facebook pages, I try to keep myself busy. I am just not the type of person who can relax for several days. Even when I am on holiday I like to check my phone too and interact on Facebook. (Male, 28)

Another respondent mentioned:

I follow TheBlondeSalad on Facebook, Twitter and on her Blog. Every evening I check out the latest posts and fashion tips whilst watching TV. (Female, 27)

Therefore, the following research proposition emerges:

RP6: Need for activity is positively related to the a) cognitive processing dimension of $O C E, b$ ) emotional dimension of $O C E$ and c) behavioural dimension of $O C E$.

\section{Need for learning}

Need for learning is a motivating factor that leads individuals to obtain information and be engaged in high-level information processing, and to seek a deep understanding of the entire environment (Mowen, 2000). A need for learning has the power to inspire individuals to increase their knowledge and thus feel an enjoyment in learning new things (Harris, Mowen, \& Brown, 2005). It is therefore important for the underlying study as many customers may join an online brand community to obtain information from peers and keep up to date and informed with the latest products and services (Harris et al., 2005). One respondent mentions:

I engage with the Dior Facebook page three times per week and sometimes daily to check their offers and new product releases because I always want to be up to date with the recent products and prices. I like to watch their make-up tutorials too. (Female, 25)

Another respondent says: 
I follow the BMW Facebook page as it provides interesting information to car-obsessed people like me. (Male, 24)

Finally, another interviewee mentions:

I engage daily with the Tagesschau [German news programme] Facebook page as I like to be up to date with the latest news and things that are happening around the world. (Male, 29)

Hence, the following research proposition is suggested:

RP7: Need for learning is positively related to the a) cognitive processing dimension of OCE, b) emotional dimension of $O C E$ and c) behavioural dimension of $O C E$.

In total, 25 out of 28 participants stated that need for learning drives their engagement with Facebook brand pages, which shows the importance of investigating the four traits additional to the Big Five.

\section{Need for arousal}

Need for arousal is defined as the desire for stimulation and excitement (Mowen, 2000; Mowen \& Spears, 1999) and has been found to be important in consumer settings as consumers buy products and services for the feelings that they provide (Holbrook \& Hirschman, 1982; Raju, 1980; Zuckerman, 1979). Moreover, as people have different levels of arousal, they seek different kinds of activities (Holbrook \& Hirschman, 1982) linked to excitement-seeking (Mowen \& Spears, 1999). This study argues that people with high levels of arousal seek more thrilling activities (Mowen \& Spears, 1999), of which individuals feel the need to share with peers in their social networks or online communities (Hardey, 2011). Therefore, a positive 
relationship between need for arousal and online customer engagement is proposed, although no support was found in the interviews.

RP8: Need for arousal is positively related to the a) cognitive processing dimension of OCE, b) emotional dimension of $O C E$ and c) behavioural dimension of OCE.

\section{Altruism}

Altruism as a personality trait (Rushton, Chrisjohn, \& Fekken, 1981) may be defined as the general predisposition to selflessly seek to help others (Mowen \& Sujan, 2005). Some individuals are just more generous, more helpful and kind to others and hence are perceived as more altruistic in nature (Dlugokinski \& Firestone, 1973; Rutherford \& Mussen, 1968). Customer engagement behaviour comprises helping other customers, for example, in terms of word-of-mouth or through feedback (Verleye et al., 2013). Accordingly, altruistic respondents mentioned:

I engage with the Lush Facebook page. When I experience a good product I immediately recommend it to others, as I like to help others. Once I tried a mask for absorbing oils and reducing acne or blemishes on the face and it was terrific. I immediately recommended it to a friend with skin problems. I even shared it on my own Facebook profile page and wrote about my experience on the Lush Facebook page to help others that are not sure which product to choose. (Female, 36)

Another respondent highlighted:

I became part of the Weight Watchers Facebook group when I started to lose weight. It's always good to talk to people that are in the same situation and I feel so much 
healthier now that I lost weight. I regularly interact there as I want to motivate others that might struggle with losing weight to show them that it's possible and give them some strength to keep up and fight for their goals. (Female, 25)

The quotes show that individuals high on altruism tend to engage a lot online as they like to help other individuals, whether friends or strangers, in different types of situations. They like to recommend products they just used or share all kinds of experiences, whether positive or negative. In total, 13 out of 28 interviewees stated that the personality trait of altruism drives their online engagement. Hence, the following research proposition is proposed:

RP9: Altruism is positively related to the a) cognitive processing dimension OCE, $b$ ) emotional dimension of $O C E$ and c) behavioural dimension of $O C E$.

\section{Online customer engagement and customer-perceived value}

Past studies have not only hypothesised a relationship between online brand community practices and customer value (Misra et al., 2008; Porter et al., 2013; Schau et al., 2009; Seraj, 2012), they have also suggested that online customer engagement might be related to value creation (Higgins \& Scholar, 2009; Hollebeek, 2013; Jaakkola \& Alexander, 2014; Kumar, Aksoy, et al., 2010).

Engagement might explain why some online communities may have more visitors than others. Hence, this study proposes that engagement is linked to a value perception by customers, which explains the difference between successful and failing online communities (Hollebeek, 2013; Seraj, 2012). Value can be seen as a jointly created phenomenon emerging through interaction (Vargo \& Lusch, 2008). If an individual is highly engaged he/she will derive intrinsic and extrinsic value from this focus on the engagement (Vivek et al., 2012) and thus the strength of 
engagement contributes to the strength of value. Accordingly, the more engaged an individual is in approaching a target (e.g. brand), the more value can be obtained (Hollebeek, 2013). This study further argues that different types of value emerge as a result of engaging online. These different types are namely: social value, play, efficiency, excellence, aesthetic value and altruistic value (Holbrook, 1999).

\section{Social value}

A relationship between customer engagement in online brand communities and social value is expressed in the following statements:

I engage with the Louis Vuitton Facebook page, as I want to stay up to date. I like to be the first one who knows about new bags so I am the first to tell my friends about it. (Female, 24)

Another respondent argues:

I engage with the Rolex Facebook page, as the social events are great to meet people who share the same passion for world-class luxurious watches. (Male, 37)

\section{Another respondent mentions:}

I recently joined a gym and I am also a member of its Facebook community. The brand Equinox stands for the really fit people. Even though I am not that fit and well shaped yet the interaction with the brand on Facebook and Twitter reminds me daily of my promise to myself. It shows others that I am committed to my goals and makes a good impression on others. (Male, 25) 
These quotes show that the individuals engage online because this engagement improves the way they are perceived by others as well as by themselves. They can therefore make a good impression in being the first to know about new releases or having general knowledge of products that are important for their peers. The quotes show that the engagement with the brand delivers social value to the respondents. In total, 7 out of 28 interviewees stated that they perceive social value after engaging with a Facebook brand community.

\section{Play}

Play is a hedonic value and arises from an individual's own pleasure in engaging online. It may make members feel happy or delighted and gives them pleasure (Holbrook, 2006). This type of value was expressed by 10 interviewees as shown, for example, in the following statements:

I engage with the Instyle Facebook brand page as I love fashion. It's so much fun to check out the latest fashion trends every day. It makes my day. (Female, 23)

Another respondent states:

I love make up and it gives me great joy to browse for new make up fashion releases on the Mac Facebook page. I share most of its products with my friends also on my own Facebook page. I also contact the admin of the page to check upcoming releases, prices and delivery. (Female, 36)

\section{Efficiency}

Efficiency involves value that results from the active use of an online brand community platform (Holbrook, 2006). Members may feel that the relevance of content on the online brand community is high or that it is easy to use. In total, 8 interviewees stated that they perceive the 
value efficiency after engaging with a Facebook brand page. Evidence for the value of efficiency is expressed in the following statements:

I engage with the Financial Times Facebook page, as the content is very relevant to me. I like to be always up to date and to know what is going on in the world. I also like that it's that easy to comment and tell others your opinion on specific articles that they upload. Sometimes it's a hassle if you want to quickly comment on a newspaper article on another website you have to register first. That is quite annoying. (Male, 27)

Another respondent mentioned:

I engage with the Vodafone Facebook page as they are very interactive with their customers and reply very quickly if I have a specific question. Their page is very effective in terms of customer care. (Female, 34)

Another respondent said:

I follow the Soulfood Low Carberia Facebook page. They upload new recipes regularly, which make my life much easier. Especially when I am on diet the interaction with others in the same situation is necessary to keep on going. Reading about others' experiences and health suggestions keeps me motivated. (Female, 22)

\section{Excellence}

Excellence, in comparison to efficiency, is seen as reactive as it results from appreciating, admiring or responding to some object (Holbrook, 1999). With regards to a Facebook brand community, excellence as a value can be perceived, for example, due to high-quality 
discussions in the community (Holbrook, 2006). The following quotes show examples of participants who perceived the value of excellence when engaging online. In total, 11 participants mentioned to perceive the value of excellence when engaging with Facebook brand pages.

The [Samsung] Facebook page shows me if the customers benefit from the products or not. Honest customer reviews and opinions are quite important for me. For example, I needed to know about the features of Samsung S6 and S6edge and Note6 and what kind of value I would get if I would buy one of the products. Therefore I checked the other customers' experiences with the software and the hardware on their Facebook page. Customers are very supportive there. (Male, 25)

Another respondent said:

I love to engage with the Mac Facebook page as they are very innovative, the website is very well run. The information is very adequate and they provide detailed information that the customer really needs. In comparison to other make-up brands this one is my absolute favourite. (Female, 36)

\section{Aesthetic value}

Aesthetic value can occur when aesthetic aspects of the online brand community lead to value creation like an easy to use layout or an attractive design as discussed by the following respondents:

I engage with the Vodafone Facebook page as their display of the page is easy and you can access information very quickly. They even have an "ask a question button" where you can ask a specific question to a community manager. Their advertisements posted are always very attractive and eye-catching. (Female, 34) 
Another respondent mentioned:

The Victoria Secret Facebook page is one of my favourites. It's extremely interesting and I check it five times per week especially in summer to check new swim suits releases and the new beach stuff and lingerie. The images posted are very colourful and just inspiring to look at and I also love the videos they upload on the page. (Female, 21)

In total, 7 interviewees mentioned that they perceive aesthetic value when engaging with a Facebook brand page.

\section{Altruistic value}

Altruistic value occurs if the purpose of individuals engaging online is to help peers. It involves doing something for the sake of others and it includes the concern of how others will react or how they will be affected (Holbrook, 1999). The relationship between altruistic value and online customer engagement was discussed by 11 out of 28 respondents for example they noted that:

I engage with the Holland \& Barrett Facebook page because I want to share my experiences with people. I live a healthy lifestyle and I am obsessed with the vitamins and skincare products. Therefore, I visit the Holland \& Barrett Facebook page to check their offers and read other customer reviews. (Female, 26)

Another respondent argues:

I engage with the Lancôme Facebook page as I feel like I have to share my experiences with the products with other users. I feel like sharing my experience really makes a difference to some people and I also rely on others' recommendations too. It's a give and take. (Female, 32) 
Another respondent mentions:

I engage with many skincare Facebook pages. One of the most frequently used is the Clinique Facebook page. I like to try new products and change my moisturiser regularly because I might find a better one. If I don't share my experiences, good or bad in nature, others might do the same mistake and buy the same overpriced product. I feel like I have to protect others from making the same mistakes I made. (Female, 28)

Most of the statements about the engagement or interaction between the customer and the brand reflect at least one of the three dimensions (cognitive, emotional and behavioural) of which customer engagement is comprised. Many reflected all of the dimensions, and all have been seen to be positively related to the different types of customer-perceived value. The findings of the exploratory interviews also suggest that customer-perceived value is seen as a consequence of customer engagement in online brand communities. Many of the above statements indicate that the value is perceived after the engagement with the brand. Therefore, based on the findings from the interviews, it is proposed that:

RP10: Positively valenced online customer engagement (cognitive, emotional and behavioural) is positively related to a) social value, b) play, c) excellence, d) efficiency, e) aesthetic value and f) altruistic value.

The following conceptual framework summarises the research propositions previously developed (see Figure 1). The personality traits and perceived customer value types marked with an asterisk have been empirically found to be related to online customer engagement. Introversion, disagreeabless and conscientiousness, all part of the Big Five personality traits have been found to be negatively related to engagement with Facebook brand pages. There was no support for neuroticism to drive online engagement whereas openness to experience has 
been found to be positively related to online engagement. Four additional traits have been investigated and empirical support was found for three of these traits driving online engagement, namely: need for activity, need for learning and altruism. Six different forms of value have been perceived by individuals engaging with various Facebook brand pages, namely: social value, play, efficiency, excellence, aesthetic value and altruistic value.

$* * * * * * * * * * * * * * * * * * * * * * * * * * * * * * * * * * * * * * *$

INSERT FIGURE 1 ABOUT HERE

Figure 1 Conceptual framework of online customer engagement.

\section{Managerial implications}

Building a better understanding of why, and how, customers choose to engage with brands in online environments is a critical part of building brand equity in the digital economy. Online customer engagement now spans a full range of marketing activity, from customer complaints through to new product launches. Yet, despite the considerable investment made by marketers in various forms of online brand community - whether online forum or social media brand 
community, many of these communities suffer from a lack of use. By building understanding of how customers perceive the value that they receive from engaging in these communities, managers are in a better position to design communities anchored in customer value expectations. This study is the first to show insights into an increased number of possible personality traits that drive online customer engagement and highlights six different forms of value that might be perceived by customers. Further research validating these findings on a broader scale could result in specific managerial implications for the companies investigated. Thus, future studies are needed to test the proposed framework through large-scale quantitative research into personality traits and customer-perceived value in distinct Facebook brand pages or firm-hosted online brand communities. Structural Equation Modelling is suggested to be used to validate the strength and directions of the relationships. The findings will help managers of these distinct online brand communities to get a better understanding of customer behaviour in an online context by revealing which personality traits drive online engagement of users and what kind of customer-perceived value is received by individuals engaging online. Consequently, the company will be able to better segment their customers through a more detailed understanding of the traits of those who engage in their specific online communities. Having better understood the role of engagement firms can then apply this knowledge to make their online communities more effective. For example, in order to meet customer needs for efficiency when using online communities firms should implement technology to improve the provision of content targeted on an individual level. Additionally, firms need to prioritise investment in user experience to minimise the effort customers expend in day-to-day use of these communities, particularly due to the growth in multi-platform internet use. Customer relationship management remains a key marketing priority (Verhoef et al., 2010), and thus developing attractive social media and online brand communities is of high importance because they build a more effective platform for customer co-creation and enable customers to actively contribute to the development of ideas and concepts, while also facilitating the creation of bonds 
between brand and customers. Findings of this study set the foundation stone and show support for the importance of further broader scale research in this area that will be able to improve specific online brand communities accordingly.

\section{Conclusion, limitations and future research directions}

This paper reviewed literature on the concept of customer engagement. The paper further focuses on personality traits as an antecedent and customer-perceived value as a consequence of customer engagement in social media brand communities, as revealed by the exploratory interviews. A conceptual framework was built as a result of a discussion about research propositions, which have been supported by the findings of the exploratory interviews conducted. Seven out of the nine personality traits were found to be related to online customer engagement, namely: introversion/extroversion, (dis)agreeableness, conscientiousness, openness to experience, need for activity, need for learning and altruism. Moreover, findings suggest that customers engaging in Facebook brand communities perceive six different forms of customer value, namely: social value, play, efficiency, excellence, aesthetic and altruistic value.

These findings improve our understanding of online customer engagement in empirically investigating the concepts of personality traits as antecedents and the concept of customerperceived value as a consequence of online customer engagement. This research addresses a gap in existing customer engagement literature; there is a lack of research to date into customerperceived value as a consequence of online customer engagement. Moreover, the study proposes four new personality traits in addition to the Big Five as antecedents of online customer engagement. Interviews yielded support for three of these personality traits, namely: need for learning, need for activity and altruism. Thus, this study provides insights into the 
relationship of personality and online customer engagement, as research focusing on personality traits in an online environment is still scarce.

As with any piece of research this study faces some limitations, including those related to the self-reporting of personality traits (despite this being a commonly used method (e.g.Coelho, 2010)) and the potential for social desirability bias as respondents may want to present themselves in a favourable light (Furnham, 1986). Nevertheless, interviews revealed that social desirability is not a significant issue in this study. Further research limitations include a limited sample size; future research is encouraged to further investigate the topic using a quantitative research approach, as some respondents might not be able to explicitly state which traits drive their online engagement. The research could take place with an extensive number of users of a distinct, firm-hosted online brand community or social media brand community in order to be able to provide customised, company-specific managerial implications for improving their online brand community. Moreover, the research findings might be different for a firm-hosted online brand community that exists independently from a social media site because customers engaging in such communities might be more devoted to them than those engaging in social media brand communities (Ouwersloot \& Odekerken-Schröder, 2008). Since engaging in and joining a firm-hosted online brand community requires customers to register with these communities rather than just hitting a like button, customers who do make this extra effort are likely to be more committed to the community (Koh, Kim, \& Kim, 2003; Muñiz \& O'Guinn, 2001). Consequently, the engagement of members might be higher in firm-hosted online brand communities as they actively contribute to the community, co-create content and have a feeling of responsibility for the community (Andersen, 2005; Paderni et al., 2014). Future research might also test whether the framework holds for a firm-hosted online brand community. 
Despite these limitations, this study serves to extend the customer engagement literature through providing valuable insights on how personality traits and customer-perceived value are related to online customer engagement. Since the domain of online customer engagement is critical to the success of many firms, continued research into the many factors surrounding this key construct remains an imperative. 


\section{References}

Ajzen, I. (2005). Attitudes, personality and behaviour (Vol. 2). Maidenhead: Open University Press.

Algesheimer, R., Dholakia, U. M., \& Hermann, A. (2005). The social influence of brand community: Evidence from European car clubs. Journal of Marketing, 69(1), 19-34. doi:http://dx.doi.org/10.1509/jmkg.69.3.19.66363

Amichai-Hamburger, Y., \& Ben-Artzi, E. (2000). The relationship between extraversion and neuroticism and the different uses of the internet. Computers in Human Behavior, 16(1), 441-449. doi:10.1016/S0747-5632(00)00017-0

Amichai-Hamburger, Y., \& Ben-Artzi, E. (2003). Loneliness and internet use. Computers in Human Behavior, 19(1), 71-80. doi:10.1016/S0747-5632(02)00014-6

Amichai-Hamburger, Y., \& Vinitzky, G. (2010). Social network use and personality. Computers in Human Behavior, 26(1), 1289-1295. doi:10.1016/j.chb.2010.03.018

Andersen, P. H. (2005). Relationship marketing and brand involvement of professionals through web-enhanced brand communities: The case of Coloplast. Industrial Marketing Management, 34(1), 39-51. doi:10.1016/j.indmarman.2004.07.002

Asendorpf, J. B., \& Wilpers, S. (1998). Personality effects on social relationships. Journal of Personaliy and Social Psychology, 74(1), 1531-1544. doi:http://dx.doi.org/10.1037/0022-3514.74.6.1531

Barrick, M. R., \& Mount, M. K. (1991). The big five personality dimensions and job performance: A meta analysis. Personnel Psychology, 44(1), 1-26. doi:10.1111/j.1744-6570.1991.tb00688.x

Bejerholm, U., \& Eklund, M. (2007). Occupational engagement in persons with schizophrenia: Relationships to self-related variables, psychopathology and quality life. The American Journal of Occupational Therapy, 61(1), 21-32. doi:10.5014/ajot.61.1.21

Block, J. (1995). A contrarian view of the five-factor approach to personality description. Psychological Bulletin, 117(3), 187-215. doi: http://dx.doi.org/10.1037/00332909.117.2.187

Bolton, R. N., \& Saxena-Iyer, S. (2009). Interactive Services: A Framework, synthesis and research directions. Journal of Interactive Marketing, 23(1), 91-104. doi:10.1016/j.intmar.2008.11.002

Brodie, R. J., Hollebeek, L., Juric, B., \& Ilic, A. (2011). Customer engagement: Conceptual domain, fundamental propositions, and implications for research. Journal of Service Research, 14(3), 252-271. doi:10.1177/1094670511411703

Brodie, R. J., Ilic, A., Juric, B., \& Hollebeek, L. (2013). Consumer engagement in a virtual brand community: An exploratory analysis. Journal of Business Research, 66(1), 105114. doi:10.1016/j.jbusres.2011.07.029

Brown, T. J., Mowen, J. C., Donovan, T., \& Licata, J. (2002). The customer orientation of service workers:Personality trait determinants and influences on self and supervisor performance ratings. Journal of Marketing Research, 39(1), 110. doi:http://dx.doi.org/10.1509/jmkr.39.1.110.18928

Butt, S., \& Phillips, J. G. (2008). Personality and self reported mobile phone use. Computers in Human Behavior, 24(2), 346-360. doi:10.1016/j.chb.2007.01.019

Calder, B. J., Malthouse, E. C., \& Schaedel, U. (2009). An experimental study of the relatonship between online engagement and advertising effectiveness. Journal of Interactive Marketing, 23(4), 321-331. doi:10.1016/j.intmar.2009.07.002

Catteeuw, F., Flynn, E., \& Vonderhorst, J. (2007). Employee engagement: Boosting productivity in turbulent times. Organization Development Journal, 25(2), 151-157. 
Coelho, F. (2010). Job characteristics and the creativity of frontline service employees. Journal of Service Research, 13(4), 426-438 doi:10.1177/1094670510369379

Correa, T., Willard, A. W., \& Zúniga, H. G. (2010). Who interacts on the web? The intersection of users' personality and social media use. Computers in Human Behavior, 26(1), 247-253. doi:10.1016/j.chb.2009.09.003

Costa, P. T., \& McCrae, R. R. (1992a). Four ways five factors are basic. Personality and Individual Differences, 13(6), 653-665. doi:10.1016/0191-8869(92)90236-I

Costa, P. T., \& McCrae, R. R. (1992b). Normal personality assessment in clinical practice: The NEO Personality Inventory. Psychological Assessment, 4(1), 5-13. doi:http://dx.doi.org/10.1037/1040-3590.4.1.5

Digman, J. M. (1990). Personality structure: Emergence of the five-factor model. Annual Review of Psychology, 41(1), 417-440. doi:10.1146/annurev.ps.41.020190.002221

Digman, J. M., \& Takemoto-Chock, N. K. (1981). Factors in the natural language of personality: Re-Analysis, comparison, and interpretation of six major studies. Multivariate Behavioral Research, 16(2), 149-170. doi:10.1207/s15327906mbr1602_2

Dlugokinski, E., \& Firestone, I. J. (1973). Congruence among four methods of measuring other-centeredness. Child Development, 44(1), 304-308. doi:10.2307/1128051

Dodds, W. B., Monroe, K. B., \& Grewal, D. (1991). Effects of price, brand, and store information on buyers' product evaluations. Journal of Marketing Research, 28(3), 307-319. doi: $10.2307 / 3172866$

Evans, J. (1941). A new measure of introversion - extroversion. The Journal of Psychology: Interdisciplinary and Applied, 12(1), 111-124. doi:10.1080/00223980.1941.9917060

Eysenck, H. J. (1991). Dimensions of personality: 16, 5 or 3? - Criteria for a taxonomic paradigm. Personality and Individual Differences, 12(8), 773-790. doi:10.1016/01918869(91)90144-Z

Furnham, A. (1986). Response bias, social desirability and dissimulation. Personality and Individual Differences, 7(3), 385-400. doi:10.1016/0191-8869(86)90014-0

Gosling, S. D., \& Augustine, A. A. (2011). Facebook-related behaviours and observable profile information. CyberPsychology, Behaviour and Social Networking, 14(1), 483488. doi:10.1089/cyber.2010.0087

Grönroos, C. (2000). Service management and marketing: A customer relationship approach. Chichester: Wiley.

Gummesson, E. (1994). Broadening and specifiying relationship marketing. Asia Australia Marketing Journal, 2(1), 31-43. doi:10.1016/S1320-1646(94)70276-8

Guthrie, J. T., \& Cox, K. E. (2001). Classroom conditions for motivation and engagement in reading. Educational Psychology Review, 13(3), 283-302. doi:10.1023/A:1016627907001

Hardey, M. (2011). To spin straw into gold? New lessons from consumer-generated content. International Journal of Market Research, 53(1), 13-15. doi:http://dx.doi.org/10.2501/IJMR-53-1-013-015

Harris, E. G., \& Lee, J. M. (2004). Illustrating a hierarchical approach for selecting personality traits in personnel decisions: An application of the $3 \mathrm{M}$ model. Journal of Business and Psychology, 19(1), 53-67. doi:10.1023/B:JOBU.0000040272.84608.83

Harris, E. G., Mowen, J. C., \& Brown, T. J. (2005). Re-examining salesperson goal orientations: personal influencers, customer orientation, and work satisfaction. Journal of the Academy of Marketing Science, 33(1), 19-35. doi:10.1177/0092070304267927

Higgins, E. T., \& Scholar, A. A. (2009). Engaging the customer: The science and art of the value creation process. Journal of Consumer Psychology, 19(2), 100-114. doi:10.1016/j.jcps.2009.02.002

Hirschfeld, R. R., Jordan, M. H., Thomas, C. H., \& Feild, H. S. (2008). Observed leadership potential of personnel in a team setting: Big five traits and proximal factors as 
predictors. International Journal of Selection and Assessment, 16(4), 385-402. doi:10.1111/j.1468-2389.2008.00443.x

Holbrook, M. (1999). Consumer value: a framework for analysis and research. Oxon: Routledge.

Holbrook, M. (2006). Consumption experience, customer value, and subjective personal introspection: An illustrative photographic essay. Journal of Business Research, 59(6), 714-725. doi:10.1016/j.jbusres.2006.01.008

Holbrook, M., \& Hirschman, E. C. (1982). The experiential aspects of consumption: Consumer fantasies, feelings and fun. Journal of Consumer Research, 9(2), 131-140. doi:http://www.jstor.org/stable/2489122

Hollebeek, L. (2011). Demystifying customer brand engagement: Exploring the loyalty nexus. Journal of Marketing Management, 27(7-8), 785-807. doi:10.1080/0267257X.2010.500132

Hollebeek, L. (2013). The customer engagement/value interface: An exploratory investigation. Australasian Marketing Journal, 21(1), 17-23. doi:10.1016/j.ausmj.2012.08.006

Hollebeek, L., Glynn, M. S., \& Brodie, R. J. (2014). Consumer brand engagement in social media: conceptualisation, scale development and validation. Journal of Interactive Marketing, 28(2), 149-165. doi:10.1016/j.intmar.2013.12.002

Holloway, B. B., \& Beatty, S. E. (2003). Service failure in online retailing. Journal of Service Research, 6(1), 92-105. doi:10.1177/1094670503254288

Hughes, D. J., Rowe, M., \& Lee, A. (2012). A tale of two sites: Twitter vs. Facebook and the personality predictors of social media usage. Computers in Human Behavior, 28(1), 561-569. doi:10.1016/j.chb.2011.11.001

Jaakkola, E., \& Alexander, M. (2014). The role of customer engagement behaviour in value co-creation: A service system perspective. Journal of Service Research, 17(3), 247261. doi:10.1177/1094670514529187

Judge, T. A., Erez, M., Bono, J. E., \& Thoresen, C. J. (2011). Are measures of self-esteem, neuroticism, locus of control and generalised self-efficiency indicators of a common core construct? Journal of Personality and Social Psychology, 83(3), 693-710. doi:http://dx.doi.org/10.1037/0022-3514.83.3.693

Koh, J., Kim, Y. G., \& Kim, Y. G. (2003). Sense of virtual community: A conceptual framework and empirical validation. International Journal of Electronic Commerce, 8(2), 75-94. doi:10.1080/10864415.2003.11044295

Koyuncu, M., Burke, R. J., \& Fiksenbaum, L. (2006). Work engagement among women managers and professionals in a Turkish bank. Equal Opportunities International, 25(4), 299-310. doi:http://dx.doi.org/10.1108/02610150610706276

Kumar, V., Aksoy, L., Donkers, B., Venkatesan, R., Wiesel, T., \& Tillmanns, S. (2010). Undervalued or overvalued customers: Capturing total customer engagement value. Journal of Service Research, 13(3), 297-310. doi:10.1177/1094670510375602

Kumar, V., Petersen, J. A., \& Leone, R. P. (2010). Driving profitability by encouraging customer referrals: Who, when and how. Journal of Marketing, 74(5), 1-17. doi:http://dx.doi.org/10.1509/jmkg.74.5.1

Leroi-Werelds, S., Streukens, S., Brady, M. K., \& Swinnen, G. (2014). Assessing the value of commonly used methods for measuring customer value: A multi-setting empirical study. Journal of the Academy of Marketing Science, 42(4), 430-451. doi:10.1007/s11747-013-0363-4

Licata, J. W., Mowen, J. C., Harris, E. G., \& Brown, T. J. (2003). A hierarchical personality approach for identifying the traits of high-performing service personnel. Journal of the Academy of Marketing Science, 31(3), 256-271. doi:10.1177/0092070303031003004 
Lombard, M., Snyder-Duch, J., \& Bracken, C. C. (2003). Content analysis in mass communication: Assessment and reporting of intercoder reliability. Human Communications Research, 28(4), 587-604. doi:http://dx.doi.org/10.1111/j.14682958.2002.tb00826.x

Macy, W. H., \& Schneider, B. (2008). The meaning of employee engagement. Industrial and organisational psychology, 1(1), 3-30. doi:10.1111/j.1754-9434.2007.0002.x

Madjar, N. (2008). Emotional and informational support from different sources and employee creativity. Journal of Occupational and Organizational Psychology, 81(1), 83-100. doi:10.1348/096317907X202464

Malone, G. P., Pillow, D. R., \& Osman, A. (2012). The general belongingness scale (GBS): Assessing achieved belongingness. Personality and Individual Differences, 52(3), 311-316. doi:10.1016/j.paid.2011.10.027

Matthews, G., Warm, J. S., Reinermann-Jones, L. E., Langheim, L. K., Washburn, D. A., \& Trippe, L. (2010). Task engagement, cerebral blood flow velocity and diagnostic monitoring for sustained attention. Journal of Experimental Psychology: Applied, 16(2), 187-203. doi: http://dx.doi.org/10.1037/a0019572

May, D. R., Gilson, R. L., \& Harter, L. M. (2004). The psychological conditions of meaningfulness, safety and availability and the engagement of the human spirit at work. Journal of Occupational and Organizational Psychology, 77(1), 11-37. doi:10.1348/096317904322915892

McAlexander, J. H., Schouten, J. W., \& Koenig, H. F. (2002). Building brand community. Journal of Marketing, 66(1), 38-54. doi:http://dx.doi.org/10.1509/jmkg.66.1.38.18451

McCrae, R. R., \& Costa, P. T. (1991). Adding Liebe und Arbeit: The full five factor model and well being. Personality and Social Psychology Bulletin, 17(2), 227-232. doi:10.1177/014616729101700217

McElroy, J. C., Hendrickson, A. R., Townsend, A. M., \& DeMarie, S. M. (2007). Dispositional factors in internet use: Personality versus cognitive style. MIS Quarterly, 31(1), 809-820. doi:http://www.jstor.org/stable/25148821

Miles, M. B., \& Huberman, M. A. (2013). Qualitative data analysis: A methods sourcebook. Thousand Oakes: Sage Publications.

Misra, R., Mukherjee, A., \& Peterson, R. T. (2008). Value creation in virtual communities: the case of a healthcare web site. International Journal of Pharmaceutical and Healthcare Marketing, 2(4), 321-337. doi:http://dx.doi.org/10.1108/17506120810922358

Mittal, B. (1995). A comparative analysis of four scales of consumer involvement. Psychology and Marketing, 12(7), 663-682. doi:10.1002/mar.4220120708

Mollen, A., \& Wilson, H. (2010). Engagement, telepresence and interactivity in online consumer experience: Reconciling scholastic and managerial perspectives. Journal of Business Research, 63(9-10), 919-925. doi:doi:10.1016/j.jbusres.2009.05.014

Monroe, K. B. (1979). Pricing: Making profitable decisions. New York: McGraw-Hill.

Mottram, A. J., \& Fleming, M. J. (2009). Extraversion, impulsivity and online group membership as predictors of problematic internet use. CyberPsychology \& Behaviour, 12(3), 319-321. doi:10.1089/cpb.2007.0170

Mowen, J. C. (2000). The 3M model of motivation and personality: Theory and empirical applications to consumer behaviour. Norwell: Kluwer Academic Publishers.

Mowen, J. C., \& Spears, N. (1999). Understanding compulsive buying among college students: A Hierarchical Approach. Journal of Consumer Psychology, 8(4), 407-430. doi:10.1207/s15327663jcp0804_03

Mowen, J. C., \& Sujan, H. (2005). Volunteer behavior: A hierarchical model approach for investigating its trait and functional motive antecedents. Journal of Consumer Psychology, 15(2), 170-182. doi:10.1207/s15327663jcp1502_9 
Muñiz, A. M. J., \& O’Guinn, T. C. (2001). Brand Community. Journal of Consumer Research, 27(4), 412-432. doi:10.1086/319618

Mustak, M. (2014). Value for business customers: conceptualisation, process, and evaluation. Paper presented at the 13th interantional research conference in service management, La Londe les Maures, France.

Norris, C., Pignal, J., \& Lipps, G. (2003). Measuring school engagement. Education Quarterly Review, 9(2), 25-34.

Ouwersloot, H., \& Odekerken-Schröder, G. (2008). Who's who in brand communities - and why? European Journal of Marketing, 42(5/6), 571-585. doi:http://dx.doi.org/10.1108/03090560810862516

Paderni, L. S., VanBoskirk, S., Doty, C. A., Sridharan, S., Pilecki, M., French, O., \& Egelman, W. (2014). Predictions 2015: Marketing leaders mix data, content, and insight to craft brand experiences. Forrester.

Patterson, P., Yu, T., \& De Ruyter, K. (2006). Understanding customer engagement in services. Paper presented at the Proceedings of ANZMAC 2006 conference, Brisbane.

Paunonen, S. V., \& Ashton, M. C. (2001). Big five factors and the prediction of behaviour. Journal of Personality and Social Psychology, 81(3), 524-539. doi:http://dx.doi.org/10.1037/0022-3514.81.3.524

Porter, C. E., Devaraj, S., \& Sun, D. (2013). A test of two models of value creation in virtual communities. Journal of Management Information Systems, 30(1), 261-292. doi:10.2753/MIS0742-1222300108

Prahalad, C. K., \& Ramaswamy, V. (2004). Co-creation experiences: The next practice in value creation. Journal of Interactive Marketing, 18(3), 5-14. doi:10.1002/dir.20015

Raja, U., \& John, G. (2010). The joint effects of personality and job scope on in-role performance. Human Relations, 63(7), 981-1005. doi:10.1177/0018726709349863

Raju, P. S. (1980). Optimum stimulation level: Its relationship to personality, demographics and exploratory behaviour. Journal of Consumer Research, 7(3), 272-282. doi:http://www.jstor.org/stable/2489012

Roberts, D. R., \& Davenport, T. O. (2002). Job engagement: Why it's important and how to improve it. Employee Relations Today, 29(3), 21-29. doi:10.1002/ert.10048

Rose, S., Hair, N., \& Clark, M. (2010). Online customer experience: A review of the business-to-consumer online purchase context. International Journal of Management Reviews., 13(1), 24-39. doi:10.1111/j.1468-2370.2010.00280.x

Ross, C., Orr, E. S., Sisic, M., Arseneault, J. M., Simmering, M. G., \& Orr, R. R. (2009). Personality and motivations associated with facebook use. Human Behaviour, 25(2), 578-586. doi:10.1016/j.chb.2008.12.024

Ruiz, D. M., Gremler, D. D., Washburn, D. A., \& Carrión, G. C. (2008). Service value revisited: Specifying a higher-order, formative measure. Journal of Business Research, 61(12), 1278-1291. doi:10.1016/j.jbusres.2008.01.015

Rushton, J. P., Chrisjohn, R. D., \& Fekken, G. C. (1981). The altruistic personality and the self-report altruism scale. Personality and Individual Differences, 2(4), 293-302. doi:10.1016/0191-8869(81)90084-2

Rutherford, E., \& Mussen, P. (1968). Generosity in nursery school boys. Child Development, 39(1), 755-765. doi:http://www.jstor.org/stable/1126981

Ryan, T., \& Xenos, S. (2011). Who uses Facebook? An investigation into the relationship between the Big Five, shyness, narcissism, loneliness, and Facebook usage. Computers in Human Behavior, 27(5), 1658-1664. doi:10.1016/j.chb.2011.02.004

Saks, A. M. (2006). Antecedents and consequences of employee engagement. Journal of Managerial Psychology, 21(7), 600-619. doi:http://dx.doi.org/10.1108/02683940610690169 
Sánchez-Fernández, R., Iniesta-Bonillo, A. M., \& Holbrook, M. (2009). The conceptualisation and measurement of consumer value in services. International Journal of Market Research, 51(1), 93-113. doi:10.2501/S1470785308200328

Sawhney, M., Verona, G., \& Prandelli, E. (2005). Collaborating to create: The internet as a platform for customer engagement in product innovation. Journal of Interactive Marketing, 19(4), 5-17. doi:10.1002/dir.20046

Schau, H. J., Muñiz, A. M. J., \& Arnould, E. J. (2009). How brand community practices create value. Journal of Marketing, 73(5), 30-51. doi:http://dx.doi.org/10.1509/jmkg.73.5.30

Schaufeli, W., Salanova, M., Gonzalez-Roma, V., \& Bakker, A. B. (2002). The measurement of engagement and burnout and: A confirmative analytic approach. Journal of Happiness Studies, 3(1), 71-92. doi:10.1023/A:1015630930326

Seidman, G. (2013). Self-presentation and belonging on Facebook: How personality influences social media use and motivations. Personality and Individual Differences, 54(1), 402-407. doi:10.1016/j.paid.2012.10.009

Seppälä, P., Mauno, S., Feldt, T., Hakamen, J., Kinnunen, U., Tolvanen, A., \& Schaufeli, W. B. (2009). The construct validity of the Utrecht work engagement scale: Multisample and logitudinal evidence. Journal of Happiness Studies, 10(4), 459-481. doi:10.1007/s 10902-008-9100-y

Seraj, M. (2012). We create, we connect, we respect, therefore we are: Intellectual, social and cultural value in online communities. Journal of Interactive Marketing, 26(4), 209222. doi:10.1016/j.intmar.2012.03.002

Sheth, J. N., Newman, B. I., \& Gross, B. L. (1991). Why we buy what we buy: A theory of consumption values. Journal of Business Research, 22(2), 159-170. doi:10.1016/01482963(91)90050-8

Tett, O. P., Jackson, D. N., \& Rothstein, M. (1991). Personality measures as predictors of job performance: A meta-analytic review. Personnel Psychology, 44(4), 703-742. doi:10.1111/j.1744-6570.1991.tb00696.x

Tsao, W. C. (2013). Big five personality traits as predictors of internet usage categories. International Journal of Management, 30(4), 374-386.

Vargo, S. L., \& Lusch, R. F. (2004). Evolving to a new dominant logic for marketing. Journal of Marketing, 69(1), 1-17. doi:http://dx.doi.org/10.1509/jmkg.68.1.1.24036

Vargo, S. L., \& Lusch, R. F. (2008). Service dominant logic: Continuing the evolution. Journal of the Academy of Marketing Science, 36(1), 1-10. doi:10.1007/s11747-0070069-6

Verhoef, P. C., Frances, P. H., \& Hoekstra, J. C. (2002). The effect of relational constructs on customer referrals and number of services purchased from a miltiservice provider: Does age of relationship matter? Journal of the Academy of Marketing Science, 30(3), 202-252. doi:10.1177/0092070302303002

Verhoef, P. C., Reinartz, W. J., \& Krafft, M. (2010). Customer engagement as a new perspective in customer management. Journal of Service Research, 13(3), 247-252. doi:10.1177/1094670510375461

Verleye, K., Gemmel, P., \& Rangarajan, D. (2013). Managing engagement behaviours in a network of customers and stakeholder: Evidence from the nursing home sector. Journal of Service Research, 17(1), 68-84. doi:10.1177/1094670513494015

Vivek, S. D., Beatty, S. E., \& Morgan, R. M. (2012). Customer engagement exploring customer relationships beyond purchase. Journal of Marketing Theory and Practice, 20(2), 127-145. doi:10.2753/MTP1069-6679200201

Wilson, K., Fornasier, S., \& White, K. M. (2010). Psychological predictors of young adults: Use of social networking sites. CyberPsychology, Behaviour and Social Networking, 13(1), 173-177. doi:10.1089/cyber.2009.0094 
Wirtz, J., Den Ambtman, A., Bloemer, J., Horvath, C., Ramaseshan, B., Van de Kludert, J., . . . Kandamoully, J. (2013). Managing brands and customer engagement in online brand communities. Journal of Service Management, 24(3), 223-244.

doi:http://dx.doi.org/10.1108/09564231311326978

Zaichkowsky, J. L. (1985). Measuring the Involvement Construct. Journal of Consumer Research, 12(3), 341-352. doi:http://www.jstor.org/stable/254378

Zeithaml, V. A. (1988). Consumer perceptions of price, quality, and value: A means-end model and sythesis of evidence. Journal of Marketing, 52(3), 2-22. doi:10.2307/1251446

Zuckerman, M. (1979). Sensation seeking: Beyond the level of arousal. Hillsdale: Lawrence Erlbaum Associates Inc. 


\section{About the authors}

Julia Marbach is a doctoral researcher and teaching assistant at Henley Business School at the University of Reading, UK. Her doctoral research focuses on customer engagement in online brand communities. Her research interests include (i) customer engagement behaviour (ii) digital marketing (iii) customer value and (iii) customer experience. Julia has presented papers at international conferences.

Julia is the corresponding author for this paper.

Henley Business School, University of Reading, Whiteknights Campus, RG6 6UD, UK Email: j.marbach@pgr.reading.ac.uk

Tel.: +44 (0) 1183785044

Cristiana R. Lages is an Associate Professor at Henley Business School at the University of Reading, UK, and Scholar of the Advanced Institute of Management, UK. She holds a Ph.D. in Marketing from the University of Warwick, UK. Her current research interests include (i) service delivery performance and service recovery strategies; (ii) creativity in services; (iii) eWOM; and (iv) social media. She has published in Journal of Service Research, Journal of Business Research, Journal of International Marketing, International Marketing Review, European Journal of Marketing and Journal of Services Marketing, among others.

Henley Business School, University of Reading, Whiteknights Campus, RG6 6UD, UK Email: c.r.lages@henley.ac.uk

Tel.: +44 (0) 1183787941 
Daniel Nunan is a lecturer in marketing at Henley Business School, University of Reading. He holds a PhD in marketing from Cranfield School of Management. He has published in leading journals including the Journal of Business Ethics, New Technology, Work and Employment, International Journal of Retail and Distribution Management and numerous articles in the International Journal of Market Research of which he sits on the editorial board. His research interests are in the areas of digital marketing, big data and consumer privacy.

Henley Business School, University of Reading, Whiteknights Campus, RG6 6UD, UK Email: d.f.nunan@henley.ac.uk

Tel.: +44 (0) 1183785044 